\title{
Determination of $D$ and $z$ values for Salmonella Typhimurium inoculated in an egg-based pastry
}

\author{
Determinação do valor D e z para Salmonella Typhimurium \\ inoculada em produto de pastelaria à base de ovo
}

\author{
Márcio Moura-Alves $^{1 *}$ (D), Carolina Machado ${ }^{1}$, Cristina Saraiva ${ }^{2}$, José A. Silva ${ }^{1,2}$ \\ ${ }^{1}$ Universidade de Trás-os-Montes e Alto Douro (UTAD), Escola de Ciências Agrárias e Veterinárias (ECAV), \\ Departamento de Ciências Veterinárias, Vila Real - Portugal. \\ ${ }^{2}$ Universidade de Trás-os-Montes e Alto Douro (UTAD), Centro de Ciência Animal e Veterinária (CECAV), Escola \\ de Ciências Agrárias e Veterinárias (ECAV), Departamento de Ciências Veterinárias, Vila Real - Portugal.
}

*Corresponding Author: Márcio Moura-Alves, Universidade de Trás-os-Montes e Alto Douro (UTAD), Escola de Ciências Agrárias e Veterinárias (ECAV), Departamento de Ciências Veterinárias, Laboratório de Tecnologia, Qualidade e Segurança Alimentar (TeQSA), Complexo Laboratorial, Quinta de Prados, 5000-801, Vila Real Portugal, e-mail: mmalves@utad.pt

Cite as: Alves, M. M., Machado, C., Saraiva, C., \& Silva, J. A. (2020). Determination of D and z values for Salmonella Typhimurium inoculated in an egg-based pastry. Brazilian Journal of Food Technology, 23, e2019122. https://doi.org/10.1590/1981-6723.12219

\begin{abstract}
Eggs, often used in pastry products, are one of the major transmission vehicles of Salmonella. The main purpose of this study was to evaluate Salmonella Typhimurium thermal resistance, by D and $z$ values determination, in a traditional Portuguese egg-based pastry and its microbial and physical-chemical characterization. Salmonella Typhimurium ATCC 14028 (OXOID C6000L) (Ca. $1.33 \times 10^{8} \mathrm{cfu} \mathrm{g}^{-1}$ ) was inoculated in a liquid batter consisting of 8 whole eggs, 7 egg yolks, $280 \mathrm{~g}$ of wheat flour and $250 \mathrm{~g}$ of sugar. $\mathrm{D}$ and $\mathrm{z}$ values determinations were performed after applying a water bath to vacuum-packed samples of liquid batter $(5 \mathrm{~g})$, following thermal treatments: $52^{\circ} \mathrm{C}$ $(45,90,135,180$ and $225 \mathrm{~min}) ; 55^{\circ} \mathrm{C}(15,30,45,60,70$ and $80 \mathrm{~min}) ; 58^{\circ} \mathrm{C}(5,10,15,20,25$ and $30 \mathrm{~min})$ and $61^{\circ} \mathrm{C}$ $(1,2,3,4$ and $5 \mathrm{~min})$. Physico-chemical ( $\mathrm{a}_{\mathrm{w}} \mathrm{pH}$, moisture, sugar, ashes, protein and free fat) and microbiological determinations (mesophilic microorganisms, psychrotrophic, molds and yeasts, Enterobacteriacea, E. coli; Salmonella spp., Bacillus cereus, Listeria monocytogenes and Staphylococcus aureus) were also conducted in raw liquid batter. It was possible to investigate different combinations of time and temperature for Salmonella Typhimurium inactivation, compared to other studies on egg-based batter, often used to make pastry products. Liquid batter $\mathrm{a}_{\mathrm{w}}$ before inoculation was 0.94 and $\mathrm{pH}$ 7.26. The $\mathrm{D}$ values were obtained $53.19 \mathrm{~min}, 20.45 \mathrm{~min}, 6.95 \mathrm{~min}$ and $1.60 \mathrm{~min}$, at $52{ }^{\circ} \mathrm{C}, 55^{\circ} \mathrm{C}, 58{ }^{\circ} \mathrm{C}$ e $61{ }^{\circ} \mathrm{C}$, respectively. From the calculated $\mathrm{D}$ values, the corresponding $\mathrm{z}$ value was $5.96^{\circ} \mathrm{C}$.
\end{abstract}

Keywords: Thermal resistance; Thermal inactivation; Raw batter; Contamination; Microbial characterization; Physical-chemical characterization. 


\section{Resumo}

Utilizados com frequência em produtos de pastelaria, os ovos são um dos principais veículos de transmissão de Salmonella. O presente estudo teve como objetivo a avaliação da resistência térmica de Salmonella Typhimurium, através da determinação dos valores $D$ e z na massa crua de produto de pastelaria de tradição portuguesa à base de ovo, bem como a sua caracterização microbiológica e físico-química. Salmonella Typhimurium ATCC 14028 (OXOID C6000L) (Ca. 1,33×108 ufc/g) foi inoculada na massa crua constituída por 8 ovos inteiros, 7 gemas, 280 gramas de farinha e 250 gramas de açúcar. A determinação dos valores $D$ e $z$ foi realizada após submeter as amostras embaladas a vácuo $(5 \mathrm{~g})$ em banho-maria aos seguintes tratamentos térmicos: $52{ }^{\circ} \mathrm{C}\left(45,90,135,180\right.$ e $225 \mathrm{~min}$.); $55^{\circ} \mathrm{C}\left(15,30,45,60,70\right.$ e $80 \mathrm{~min}$.); $58^{\circ} \mathrm{C}(5,10,15,20,25$ e $30 \mathrm{~min}$.) e $61^{\circ} \mathrm{C}\left(1,2,3,4\right.$ e 5 min.). Também foram realizadas determinações físico-químicas ( $a_{w}, p H$, humidade, açúcar, cinzas, proteína e gordura livre) e microbiológicas (microbiota deteriorativa: microrganismos mesófilos, psicrotróficos, bolores e leveduras, Enterobacteriacea, E. coli; microbiota patogénica: Salmonella spp., Bacillus cereus, Listeria monocytogenes e Staphylococcus aureus) na massa líquida crua. Foi possível investigar diferentes combinações de tempo e temperatura para Salmonella Typhimurium, comparativamente a outros estudos realizados em massa à base de ovo, frequentemente utilizada para a produção de produtos de pastelaria. Antes da inoculação, a $a_{w}$ foi de 0,94 e pH de 7,26. Os valores $D$ obtidos foram 53,19 min, 20,45 min, 6,95 min e 1,60 min, para $52{ }^{\circ} \mathrm{C}, 55^{\circ} \mathrm{C}, 58{ }^{\circ} \mathrm{C}$ e $61^{\circ} \mathrm{C}$, respetivamente. A partir dos valores $\mathrm{D}$ calculados, o valor z correspondente foi de $5,96^{\circ} \mathrm{C}$

Palavras-chave: Resistência térmica; Inativação térmica; Massa crua; Contaminação; Caracterização microbiológica; Caracterização físico-química.

\section{Introduction}

Salmonella is known as a versatile microorganism, that adapts to $\mathrm{pH}, \mathrm{a}_{\mathrm{w}}$ and temperature conditions beyond its growth range. Optimal temperature growth for Salmonella is about 35 to $37{ }^{\circ} \mathrm{C}$, however, it can develop between 5 to $47^{\circ} \mathrm{C}$. Furthermore, this microorganism can grow at $\mathrm{pH}$ ranges of 3.8 to 9.5 (6.5-7.5 optimal) and $\mathrm{a}_{\mathrm{w}}$ of 0.94 to 0.99 , however, below 0.94 it can remain at a latency state (D' Aoust \& Maurer, 2007; International Commission on Microbiological Specifications for Foods, 1996; Jay et al., 2005).

The main causes of Salmonella contamination in foods with low $\mathrm{a}_{\mathrm{w}}$ are inadequate hygiene practices, poor quality of facilities, and insufficient maintenance of equipment and its design (Bell \& Kyriakides, 2002; Carrasco et al., 2012). The presence of Salmonella in bakery products has been a concern in the last years. Outbreaks associated with this microorganism have been reported in custards, pies, bread and cakes, among others (Bonner \& Schweiger, 1994; Evans et al., 1996; Lathrop et al., 2014; Zhang et al., 2007). Most reported outbreaks involving bakery products are associated to eggs that are insufficiently cooked (Lathrop et al., 2014). Contamination by Salmonella through raw ingredients is a reality, as they are usually used in bakery receipts, such as eggs, chocolate, flour, peanut butter and dairy products (Arvanitoyannis \& Bosinas, 2006; Saranraj \& Geetha, 2012; Smith et al., 2004).

Salmonella resistance to stress factors as low $\mathrm{a}_{\mathrm{w}}$, lethal temperatures and acidic conditions has been approached in several studies (Bell \& Kyriakides, 2002). Thermal resistance tends to increase with the addition of humectants such as sucrose and salt with the consequent decrease of $\mathrm{a}_{\mathrm{w}}$. In addition, other factors influence the increase of thermal resistance, such as lack of oxygen, use of sub lethal incubation temperatures before heat treatment and food composition, where the presence of lipids has been mentioned as having a protective effect on microbial cells (Bell \& Kyriakides, 2002; Doyle \& Mazzotta, 2000; Peña-Meléndez et al., 2014).

The majority of reported foodborne outbreaks are associated with low $\mathrm{a}_{\mathrm{w}}$ products (Finn et al., 2013). According to Majowicz et al. (2010), 98.3 million cases of Salmonella gastroenteritis are estimated to occur worldwide yearly, with 80.3 million associated with foodborne illness. The possibility of Salmonella disease 
with a reduced number of cells $(<10)$ has been reported (Finn et al., 2013; Smith et al., 2004). Most of the outbreaks associated with Salmonella due to consumption of bakery products were caused by $S$. Enteritidis PT4, S. Enteritidis PT7, and $S$. Typhimurium. Studies confirmed that eggs are the main transmission vehicle (Smith et al., 2004).

The present study aimed to evaluate thermal resistance of $S$. Typhimurium ATCC 14028 (Oxoid C6000L), a serotype often associated with foodborne outbreaks, by inoculation in a Traditional Portuguese egg-based pastry "Cavacas de Resende".

\section{Materials and methods}

\subsection{Sampling of "Cavacas de Resende" batter}

Raw liquid batter of "Cavacas de Resende" was obtained from a local confectioner in Resende, Portugal. Its preparation was carried out with $8 \mathrm{eggs}, 7 \mathrm{egg}$ yolks, $280 \mathrm{~g}$ of flour and $250 \mathrm{~g}$ of sugar.

\subsection{Physico-chemical determinations}

All physico-chemical determinations were performed at the Laboratory of Technology, quality and food safety (Lab. TeQSA) from the University of Trás-os-Montes e Alto Douro (UTAD), Vila Real, Portugal, except for sugar evaluation that was analysed in an external laboratory.

\subsection{1 $\mathrm{a}_{\mathrm{w}}$ determination}

Batter $\mathrm{a}_{\mathrm{w}}$ determination was performed with $8 \mathrm{~g}$ of sample (in duplicate) using a Rotronic Hygroskop-DT $\mathrm{a}_{\mathrm{w}}$ meter with a probe at $25^{\circ} \mathrm{C}$ (temperature controlled by water circulator).

\subsection{2 pH determination}

pH determination was performed in duplicate, directly into samples, with a WTW 330i pH meter.

\subsubsection{Moisture determination}

Moisture content was determined by dehydrating $5 \pm 0.001 \mathrm{~g}$ of samples in duplicate, at $105{ }^{\circ} \mathrm{C}$ for 24 hours (Tan \& Mittal, 2006). The results were expressed as percentage of initial sample batter.

\subsubsection{Ashes determination}

According to the experimental procedure AACC, 08-01.01 (American Association of Cereal Chemists, $1999 \mathrm{~b}$ ), ashes were determined with $2 \pm 0.001 \mathrm{~g}$ of sample in duplicate, incinerated in muffle Nabertherm Model 180 until a light grey or constant weight was obtained. Results are expressed as percentage of initial sample.

\subsubsection{Crude protein determination}

Total nitrogen determination was performed with $1 \pm 0.001 \mathrm{~g}$, duplicate samples, by Kjeldhal method (Association of Official Analytical Chemists, 1990). The sample was initially digested in a Bejtest Inkjel apparatus, by the addition of 1 catalyst tablet-(Merck 1.15348), and $12 \mathrm{~mL}$ of concentrated sulphuric acid. Total digestion time was $1 \mathrm{~h}$ and $30 \mathrm{~min}$ (20 min at 38\% of apparatus heating capacity, $20 \mathrm{~min}$ at $75 \%$, and $60 \mathrm{~min}$ at $100 \%$ ). Subsequently, $70 \mathrm{~mL}$ of $35 \% \mathrm{NaOH}, 50 \mathrm{~mL}$ of distilled $\mathrm{H}_{2} \mathrm{O}$ and $30 \mathrm{~mL}$ of $4 \% \mathrm{H}_{3} \mathrm{BO}_{3}$ with indicators (bromocresol green and methyl red) were used for distillation. Titration was carried out with $\mathrm{HCl} 0.1 \mathrm{~N}$ solution. Distillation and titration were conducted with a VELP UDK 159 automatic apparatus. 
For the conversion from nitrogen content to protein content, Jones factors were used, 6.25 for eggs and 5.70 for wheat flour (Food and Agriculture Organization of the United Nations, 2003), taking into account the proportion of protein content of raw materials used in the batter. Results are expressed as percentage of initial sample batter.

\subsubsection{Free fat determination}

According to AACC Method 30-25.01 (American Association of Cereal Chemists, 1999a), the dehydrated sample resulting from moisture content procedure was used for free fat content determination, by extraction with $n$-hexane for 6 hours in a Soxhlet apparatus. After solvent recovery by distillation, the Soxhlet flask was dried in an oven at $100{ }^{\circ} \mathrm{C}$ for intervals of $30 \mathrm{~min}$, with intercalate cooling and weighing operations, until the weighing differences did not differ more than $0.1 \%$ of the sample batter. Results are expressed as percentage of initial sample batter.

\subsection{Microbiological determinations}

All microbiological determinations were performed at the University of Trás-os-Montes e Alto Douro (UTAD), Vila Real, Portugal. The detection and enumeration of deteriorative and pathogenic microorganisms was performed before heat treatment. for serial (10-fold) dilutions we used $0.9 \%$ isotonic saline, except when it required a selective medium. Results are expressed in $\log \mathrm{cfu}^{-1}$.

\subsubsection{Salmonella spp. detection}

According to the Australian Standards (2009a), Salmonella spp. detection was performed by diluting the sample in Buffered Peptone Water medium (OXOID CM0509), subsequently incubated at $37^{\circ} \mathrm{C}$ for 18 hours. After that, $0.1 \mathrm{~mL}$ was withdrawn into a $10 \mathrm{~mL}$ Rappaport Vassiliadis Broth with soya (Liofilchem 610175) and $1 \mathrm{~mL}$ into a tube with $10 \mathrm{~mL}$ Muller Kauffmann Tetrathionate-novobiocin broth medium (Biokar Diagnostics BK169HA), incubated at $41.5^{\circ} \mathrm{C}$ for 24 hours and $37{ }^{\circ} \mathrm{C}$ for 24 hours, respectively. From the solutions obtained, aliquots of $0.1 \mathrm{~mL}$ were spread on Xylose Lysine Deoxycholate agar (VWR CHEMICALS) and Hektoen Enteric Agar (VWR CHEMICALS) with incubation at $37{ }^{\circ} \mathrm{C}$ for 24 hours.

Five colonies of the two selective media were streaked to Nutrient Agar (Biokar Diagnostics BK185HA) and incubated at $37{ }^{\circ} \mathrm{C}$ for 24 hours. The colonies obtained were spiked on Triple Sugar Iron (Liofilchem $610055)$ and Urea agar. Tubes were incubated at $37^{\circ} \mathrm{C}$.

\subsubsection{Bacillus cereus enumeration}

Based on ISO Standard 7932 (British Standards Institution, 2004), serial (10-fold) dilutions were performed and spread on Mannitol-Egg-yolk-Polymyxine agar medium (Biokar Diagnostics BK116) supplemented with egg yolk emulsion (Biokar Diagnostics BS066) and polymyxin (Biokar Diagnostics BS007). Plates were incubated in duplicate at $30^{\circ} \mathrm{C}$ for 24 hours.

Five typical as well as presumptive colonies of Bacillus cereus were streaked on Nutrient Agar (Biokar Diagnostics BK185HA). Plates were incubated at $30^{\circ} \mathrm{C}$ for 72 hours. The confirmation of the grown colonies was performed by streaking onto Columbia agar (OXOID CM0331) supplemented with 5\% sheep blood. Plates were incubated at $30^{\circ} \mathrm{C}$ for 24 hours. After this period, a hemolytic reaction development around the colonies was indicative of the presence of $B$. cereus. 


\subsubsection{Escherichia coli enumeration}

According to ISO 16649-2 (International Organization for Standardization, 2001), serial (10-fold) dilutions were performed and incorporated into Trypone Bile X-Glucuronide agar (VWR CHEMICALS) medium. Plates were incubated in duplicate at $44{ }^{\circ} \mathrm{C}$ for 18 to 24 hours. Typical blue coloration colonies were counted.

\subsubsection{Listeria monocytogenes detection}

According to Australian Standards (2009b), the first step for L. monocytogenes detection was performed using primary enrichment of half Fraser broth (VWR CHEMICALS) and incubation at $30^{\circ} \mathrm{C}$ for 24 hours. In the second step, aliquots of $0.1 \mathrm{~mL}$ were transferred to Fraser broth (VWR CHEMICALS) with incubation at $37^{\circ} \mathrm{C}$ for 48 hours. From the cultures obtained in the first and second step, aliquots of $0.1 \mathrm{~mL}$ were spread on supplemented Oxford Agar Base (VWR CHEMICALS) and supplemented PALCAM Agar (VWR CHEMICALS) with incubation at $37^{\circ} \mathrm{C}$ for 24 to 48 hours.

Five typical as well as presumptive colonies were isolated and cultured on tryptone soya yeast extract agar (Biokar Diagnostics) and incubated at $37^{\circ} \mathrm{C}$ for 18 to 24 hours. Catalase reaction, Gram staining, haemolysis test and carbohydrate utilization were performed for confirmation.

\subsubsection{Staphylococcus aureus isolation}

For the procedure, ISO 6888-2 (International Organization for Standardization, 1999), were followed. Serial (10-fold) dilutions were performed and spread into Baird Parker agar (Biokar Diagnostics BK055) supplemented with egg yolk tellurite (Biokar Diagnostics BS060) and sulfamethazine (Biokar Diagnostics BS02808). Plates were incubated in duplicate at $37{ }^{\circ} \mathrm{C}$ for 48 hours. Five typical as well as presumptive colonies were isolated and cultured in Brain Heart Infusion broth (Biokar Diagnostics BK015HA) for 24 hours at $37^{\circ} \mathrm{C}$. Further isolates were tested for coagulase production. Clotting of rabbit plasma (Biokar Diagnostics BR00208) was verified after 4 to 6 hours and when the test was negative, after 24 hours of incubation at $37^{\circ} \mathrm{C}$.

\subsubsection{Enterobacteriaceae enumeration}

According to ISO 21528-2 (British Standards Institution, 2004), serial (10-fold) dilutions were performed and incorporated into VRBG (Violet Red Bile Glucose Agar) (VWR CHEMICALS). Plates were incubated in duplicate at $37{ }^{\circ} \mathrm{C}$ for 24 hours. Typical colonies of purple staining were counted and 5 of them were spiked to Nutrient Agar (Biokar Diagnostics BK185HA) and incubated at $30{ }^{\circ} \mathrm{C}$ for 24 hours. Then, they were subjected to biochemical confirmation by oxidase (negative reaction) and glucose fermentation in Glucose agar medium (HIMEDIA M1589) (positive reaction).

\subsubsection{Molds and yeasts enumeration}

Based on Portuguese Standard 3277-1 (Instituto Português da Qualidade, 1987b), serial (10-fold) dilutions were performed and spread on Chloramphenicol Glucose Agar culture medium (VWR CHEMICALS). Plates were incubated in duplicate at $25^{\circ} \mathrm{C}$ for 5 days.

\subsubsection{Mesophilic enumeration}

According to ISO 4833 (International Organization for Standardization, 2003), serial (10-fold) dilutions were performed and incorporated into Plate Count Agar culture medium (VWR CHEMICALS). Plates were incubated in duplicate at $30^{\circ} \mathrm{C}$ for 72 hours. 


\subsubsection{Psychrotrophic enumeration}

According to Portuguese Standard 2307 (Instituto Português da Qualidade, 1987a), serial (10-fold) dilutions were performed and incorporated into Plate Count Agar culture medium (VWR CHEMICALS). Plates were incubated in duplicate at $7{ }^{\circ} \mathrm{C}$ for 10 days.

\subsection{Thermal inactivation of $S$. Typhimurium}

\subsubsection{Inoculum preparation}

$S$. Typhimurium ATCC 14028 (OXOID C6000L) culture was preserved at $-20{ }^{\circ} \mathrm{C}$ in BHI (Brain Heart Infusion) (Biokar Diagnostics BK015HA) supplemented with 25\% (v/v) of glycerol (Panreac). Bacterial strain was subcultured in BHI (Brain Heart Infusion) (VWR CHEMICALS) and incubated at $37^{\circ} \mathrm{C}$ for 24 hours, followed by subculture to XLD (Xylose Lysine Deoxycholate agar) (VWR CHEMICALS) and HKT (Hektoen Enteric agar) (VWR CHEMICALS) followed by incubation at $37^{\circ} \mathrm{C}$ for 24 hours. Isolated colonies were subcultured in BHI (Brain Heart Infusion) (VWR CHEMICALS) and incubated at $37{ }^{\circ} \mathrm{C}$ for 24 hours. Then, cultures were transferred to sterile centrifugal tubes and centrifuged at $10.000 \mathrm{x}$ g for $10 \mathrm{~min}$ at $4{ }^{\circ} \mathrm{C}$ in a Sigma $3 \mathrm{k} 18$ centrifuge. The supernatant was decanted and the pellet suspended in sterile $0.9 \%$ isotonic saline. The washing procedure was repeated 3 times. Standardized concentration $\left(6.64 \times 10^{9} \mathrm{cfu} \mathrm{mL}^{-1}\right)$ was determined by optical density (O.D. 1.2) at $600 \mathrm{~nm}$,followed by successive decimal dilutions $(1: 10)$ in $0.9 \%$ isotonic saline and confirmation of viable cells of the microorganism in XLD (Xylose Lysine Deoxycholate agar) (VWR CHEMICALS). The plates were incubated at $37^{\circ} \mathrm{C}$ for 24 hours.

\subsubsection{Inoculation and heat treatment}

The samples were prepared in triplicate with $5.0 \pm 0.1 \mathrm{~g}$ and placed in COMBITHERM bags $(93 \mathrm{~mm}$ width x $200 \mathrm{~mm}$ length x $0.08 \mathrm{~mm}$ thickness). Inoculation was performed with $0.1 \mathrm{~mL}$ from $S$. Typhimurium suspension $\left(6.64 \times 10^{9} \mathrm{cfu} \mathrm{mL}^{-1}\right)$, resulting in $1.33 \times 10^{8} \mathrm{cfu} \mathrm{g}^{-1}$, homogenizing the sample with the inoculated culture. Then, the bags were sealed under vacuum (99\%) with a SAMMIC V-420 SGA vacuum sealer machine.

Subsequently, samples were submitted to a water bath at $52{ }^{\circ} \mathrm{C}$ during $45,90,135,180,225 \mathrm{~min}$, at $55^{\circ} \mathrm{C}$ during $15,30,45,60,70$ and $80 \mathrm{~min}$, at $58{ }^{\circ} \mathrm{C}$ during $5,10,15,20,25$ and $30 \mathrm{~min}$ and at $61{ }^{\circ} \mathrm{C}$ during 1, 2, 3, 4 and $5 \mathrm{~min}$. Sample core temperature was monitored continuously using thermocouples inserted into a non-inoculated control sample.

\subsubsection{S. Typhimurium enumeration}

After samples cooling in an ice bath $\left(4^{\circ} \mathrm{C}\right)$ for $10 \mathrm{~min}$, enumeration of $S$. Typhimurium heat treatment survivors was carried out by dilution of each sample in $22.5 \mathrm{~mL}$ of sterile $0.9 \%$ isotonic saline, followed by maceration in a stomacher for 90 seconds at room temperature. Sample dilutions (1:10) were spread plated on XLD (Xylose Lysine Deoxycholate agar) (VWR CHEMICALS). The plates were incubated at $37^{\circ} \mathrm{C}$, for 24 hours. Results of the typical colonies enumeration are expressed as log cfu $\mathrm{g}^{-1}$.

\subsection{4 $\mathrm{D}$ and $\mathrm{z}$ values determination}

D values were determined by plotting the $\log _{10}$ of the survived microorganisms against the correspondent heating times, for each temperature, to obtain a regression line $(y=m x+b)$. The slope was used to determine the $\mathrm{D}$ value by the expression $\mathrm{D}=-1 / \mathrm{m}$. A minimum set of heating times was needed in order to obtain a linear relationship with more than 5 points, with correlation coefficients $(r)>0.90$ (International Organization 
for Standardization, 2006). The expression $\mathrm{z}=-1 / \mathrm{m}$ was used to calculate $\mathrm{z}$ values and it was obtained from the negative slope of the regression line over the $\log _{10}$ of $\mathrm{D}$ values at the corresponding temperatures.

\section{Results and discussion}

\subsection{Microbiological determinations before heat treatment}

For non-inoculated samples without heat treatment, pathogenic microorganisms such as L. monocytogenes, B. cereus, Salmonella spp. and S. aureus were not detected. No counts were obtained for E. coli, which demonstrates a good microbiological quality of the batter before heat treatment application. These parameters are good indicators of the raw materials quality, mainly eggs, that presents greater susceptibility of pathogenic microorganisms' development. Similarly, Pajohi-Alamoti et al. (2016) reported non-contamination of L. monocytogenes, E. coli and Salmonella in 80 pastry cream samples.

On the other hand, the counts obtained for mesophilic microorganisms were $4.02 \pm 0.10 \log \mathrm{cfu} \mathrm{g}^{-1}$; $2.57 \pm 0.04 \log \mathrm{cfu} \mathrm{g}^{-1}$, for Enterobacteriaceae; for psychrotrophic microorganisms, $3.51 \pm 0.06$; and for molds and yeasts, $2.31 \pm 0.06 \mathrm{log} \mathrm{cfu} \mathrm{g}^{-1}$ (mostly molds). Comparatively, similar counts were reported in cream pastry samples by Pajohi-Alamoti et al. (2016), $3.90 \pm 0.29 \mathrm{log} \mathrm{cfu} \mathrm{g}^{-1}$ for mesophilic microorganisms, $2.70 \pm 1.43 \log \mathrm{cfu} \mathrm{g}^{-1}$ for coliforms and $2.68 \pm 1.20 \mathrm{cfu} \mathrm{g}^{-1}$ for molds. However, in that study the products were heat-treated.

\subsection{Physic-chemical determinations before heat treatment}

Table 1 shows physic-chemical results of raw liquid batter of "Cavacas de Resende".

According to the range of $\mathrm{a}_{\mathrm{w}}, 0.94-0.99$ (International Commission on Microbiological Specifications for Foods, 1996), for Salmonella growth, 0.944 obtained for "Cavacas de Resende" is at the minimum growth limit. Furthermore, the ability of some Salmonella serotypes to survive in environments with $\mathrm{a}_{\mathrm{w}} \leq 0.85$ and dry environments has already been demonstrated (Kapperud et al., 1990; Peña-Meléndez et al., 2014). The $\mathrm{pH}$ value obtained, 7.26, is in the range of optimum $\mathrm{pH}$ for Salmonella grow (6.5-7.5) (D' Aoust \& Maurer, 2007; International Commission on Microbiological Specifications for Foods, 1996; Jay et al., 2005).

Channaiah et al. (2017), reported $\mathrm{a}_{\mathrm{w}}$ value of $0.924 \pm 0.001$, and $\mathrm{pH}$ of $6.61 \pm 0.12$ before cooking in Muffins batter. The higher $\mathrm{a}_{\mathrm{w}}$ values obtained in raw liquid batter of "Cavacas de Resende" can be explained by the reduced content of dry ingredients comparatively to those used in Muffins, like flour, granulated sugar, baking powder, salt, non-fat dry milk, whole egg solids and all-purpose shortening.

Table 1. Physico-chemical parameters of "Cavacas de Resende" raw liquid batter.

\begin{tabular}{ccccccc}
\hline $\mathbf{p H}$ & $\mathbf{a}_{\mathbf{w}}$ & Moisture (\%) & Sugar (\%) & Free Fat (\%) & Crude Protein (\%) & Ash (\%) \\
\hline 7.26 & 0.944 & 39.92 & 26.45 & 12.13 & 8.51 & 1.04 \\
\hline $\mathrm{a}_{\mathrm{w}}-$ Water activity. & & & &
\end{tabular}

\section{3 $\mathrm{D}$ and $\mathrm{z}$ values}

Thermal inactivation for $S$. Typhimurium ATCC 14028 in the batter of "Cavacas de Resende at $52{ }^{\circ} \mathrm{C}, 55^{\circ} \mathrm{C}$, $58^{\circ} \mathrm{C}$ e $61{ }^{\circ} \mathrm{C}$ is shown in Figure $1 . \mathrm{D}$ values obtained from the negative inverse of the regression line slope were: $\mathrm{D}_{52}=53.19 \pm 0.16 \mathrm{~min}, \mathrm{D}_{55}=20.45 \pm 0.96 \mathrm{~min}, \mathrm{D}_{58}=6.95 \pm 0.67 \mathrm{~min}$, and $\mathrm{D}_{61}=1.60 \pm 0.04 \mathrm{~min}$. 

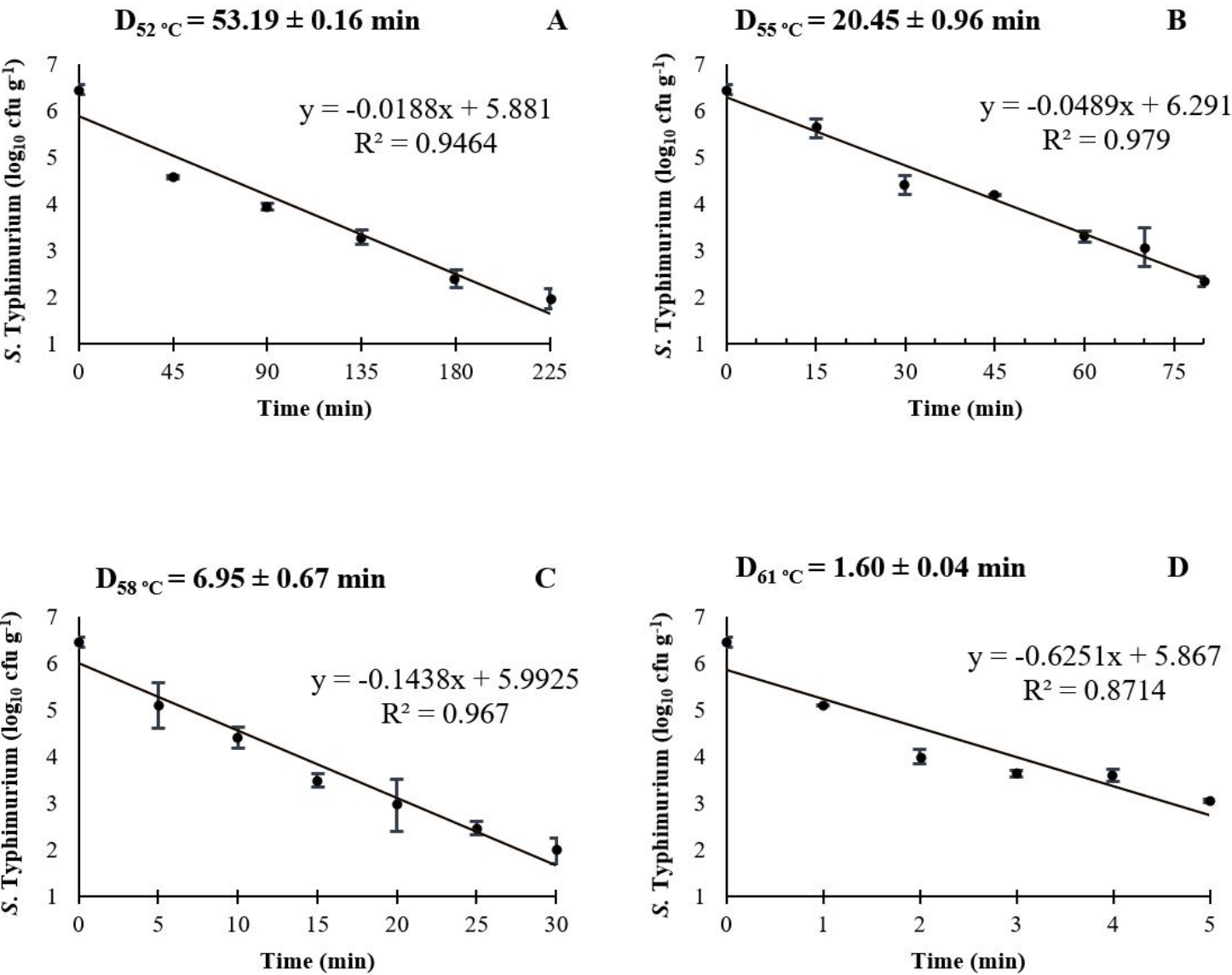

Figure 1. Thermal inactivation for S. Typhimurium ATCC 14028 in "Cavacas de Resende" batter (A, B, C, D). $\mathrm{R}^{2}$ : R Square value; Slope and $\mathrm{y}$ intercept equation $(\mathrm{y}=\mathrm{mx}+\mathrm{b})$.

Figure 2 represents the linear regression constructed for $\mathrm{z}$ value determination of $S$. Typhimurium ATCC 14028 in "Cavacas de Resende" batter, obtained from the negative slope of the regression line over the $\log _{10}$ of $\mathrm{D}$ values at the corresponding temperatures $(\mathrm{y}=-0.1678 \mathrm{x}+10.501)$. The calculated $\mathrm{z}$ value was $5.96 \pm 0.06{ }^{\circ} \mathrm{C}$.

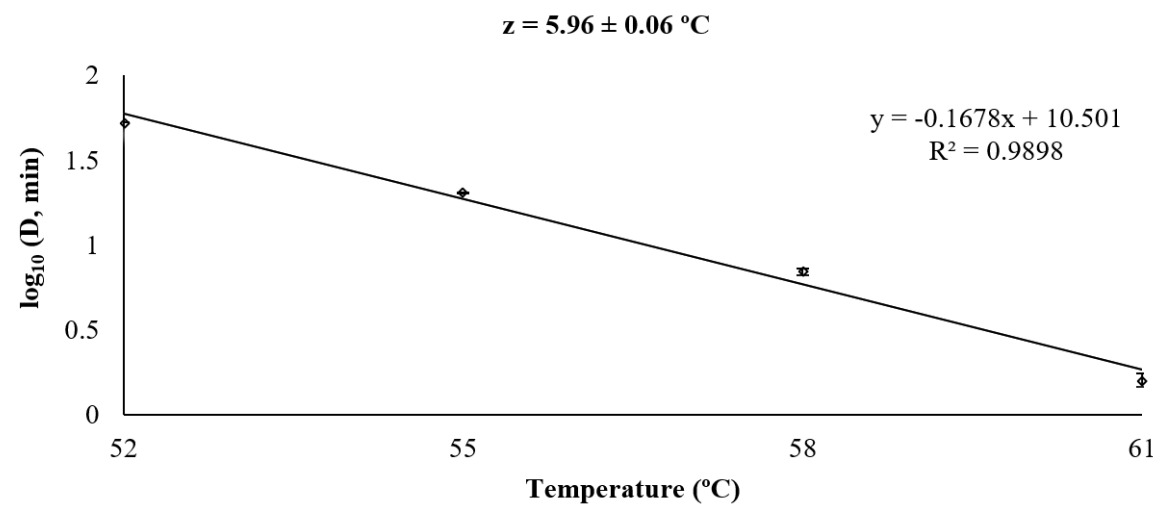

Figure 2. z value for $S$. Typhimurium ATCC 14028 in "Cavacas de Resende" batter.

Baking or cooking should destroy any Salmonella spp. present, but the degree of inactivation will depend on a number of inter-related factors. Several studies have demonstrated the influence of intrinsic and extrinsic factors in Salmonella thermal resistance. Decrease of $\mathrm{a}_{\mathrm{w}}$, exposure to sublethal temperatures before heat 
treatment, low $\mathrm{pH}$, absence of oxygen and food composition play an important role, increasing the microorganism's thermal resistance. An increase in Salmonella thermal resistance has been mentioned as related with the addition of humectants agents like sugar, as well as the presence of lipids in food composition that may cause a protective effect on the microorganism (Bell \& Kyriakides, 2002; Doyle \& Mazzotta, 2000; Peña-Meléndez et al., 2014).

In similar studies, Angelotti et al. (1961) reported a D value of $11.32 \mathrm{~min}$ at $60{ }^{\circ} \mathrm{C}$ for $S$. Senftenberg $775 \mathrm{~W}$ inoculated in custard. Besides, Channaiah et al. (2017), inoculated a cocktail of $S$. Newport, $S$. Typhimurium and $S$. Senftenberg $775 \mathrm{~W}$, in flour that was mixed with the remaining ingredients to cook Muffins, obtained D values of $62.16 \pm 2.99 \mathrm{~min}, 40.09 \pm 0.88 \mathrm{~min}$ and $16.46 \pm 1.71 \mathrm{~min}$, at 55,58 e $61{ }^{\circ} \mathrm{C}$ respectively, with a $\mathrm{z}$ value of $10.40 \pm 0.63{ }^{\circ} \mathrm{C}$. It can be verified that the values reported by these authors are higher than the values showed in Figures 1 and 2. However, considering the differences in thermal resistances of between Salmonella serotypes, mainly $S$. Senftenberg $775 \mathrm{~W}$, which is considered one of Salmonella serotypes most resistant to high temperatures (Ng et al., 1969), these differences are predictable. Food composition may also explain the differences in Salmonella thermal resistance reported in different studies. D'Aoust (1989) highlighted the influence of sugar concentration in $S$. Typhimurium and $S$. Senftenberg $775 \mathrm{~W}$ thermal resistance between $55^{\circ} \mathrm{C}$ and $75^{\circ} \mathrm{C}$. Thermal resistance increased in sucrose solutions as $\mathrm{a}_{\mathrm{w}}$ decreased from 0.995 to 0.706 . Studies using eggs have been also carried out on thermal resistance of Salmonella. Garibaldi et al. (1969) obtained a $\mathrm{D}_{60}$ values of $0.60 \mathrm{~min}$ and a $\mathrm{z}$ value of $4.6{ }^{\circ} \mathrm{C}$ for $S$. Typhimurium in eggs containing $10 \%$ sucrose. The same authors reported a $\mathrm{D}_{60}$ value of $1.0 \mathrm{~min}$ and a z value of $5.3{ }^{\circ} \mathrm{C}$ for $S$. Typhimurium in eggs containing egg yolk and corn syrup enhancing thermal resistance, increase with the addition of other ingredients. Garibaldi et al. (1969), also reported $\mathrm{D}_{58.8}$ and $\mathrm{D}_{60}$ values of 0.7 and $0.4 \mathrm{~min}$ respectively, with a $\mathrm{z}$ value of $4.4{ }^{\circ} \mathrm{C}$. Palumbo et al. (1995), also reported $\mathrm{D}_{60}$ values of 4.0 and $5.1 \mathrm{~min}$ with a $\mathrm{z}$ value of $4.8^{\circ} \mathrm{C}$ for $S$. Typhimurium in egg yolk with the addition of $10 \%$ sucrose and in egg yolk with the addition of $10 \% \mathrm{NaCl}$, respectively. Comparing these studies, $\mathrm{D}$ and $\mathrm{z}$ values obtained for "Cavacas de Resende" batter are higher. This finding suggests that the addition of flour and sugar may have contributed to the increase in $S$. Typhimurium thermal resistance.

Likewise, wheat flour has been demonstrated to increase Salmonella thermal resistance compared to other foods. The destruction curves of $S$. Weltevreden at different $\mathrm{a}_{\mathrm{w}}$, showed a rapid death in the first $5-10 \mathrm{~min}$, followed by a slower and more linear destruction (Archer et al., 1998). Even though flour is not the main ingredient in "Cavacas de Resende", a higher rate of destruction of the microorganism in the first minute, followed by a slower rate of destruction also occurs. This may be related to the changes of the physical state of the batter promoted by heat. So, at the beginning, the liquid batter allows a greater destruction of the microorganisms. Due to baking, the batter becomes more solid, providing protection to the microorganisms, since the increase of solid particles is a factor for increasing the resistance of microorganisms (Blackburn et al., 1997).

Some protective mechanisms in microorganisms that present grant superior resistance to stress factors have been studied. Finn et al. (2013) reported that one of the microorganisms resistance mechanisms is the accumulation of osmoprotective molecules (betaine (N,N,N-trimethyl glycine), proline for example), cell filamentation, the presence of regulatory genes, and biofilm formation. Under stress conditions, microorganisms can express specific genes to respond quickly to adverse conditions (Mattick et al., 2000). Tapia et al. (2007) suggested that the increase in thermal resistance occurs due to the reduced presence of water that diminishes molecular vibrations as the cells are heated. When the water content is high, the molecular vibrations increase, causing protein denaturation, ribosomal damage and enzymes inactivation, and consequently, the inactivation of microorganisms (Mackey et al., 1991; Nguyen et al., 2006). 


\section{Conclusions}

Based on the results, reduction of Salmonella is expected to occur in bakery products for combinations of time and temperature that exceed the resistance of the microorganism. In this particular study, $1.60 \mathrm{~min}$ at $61{ }^{\circ} \mathrm{C}$ is sufficient to inactivate Salmonella Typhimurium. However, different food compositions may hinder Salmonella inactivation. Not reaching the appropriate temperatures and times, mainly in the thermal centre of the product, enhances the need to implement safety measures, especially in products that can support the development of Salmonella. Continuous improvement of manufacturing processes and use of good manufacturing practices should be encouraged in order to avoid post-processing contamination, since the resistance of some pathogenic microorganisms such as Salmonella increases the risk of causing consumer illness.

\section{Acknowledgements}

The authors would like to thank "Município de Resende" by their contributions, Mrs. Ana Leite and Mrs. Helena Santos for their contributions to this research and to CECAV-UTAD. Special thanks also to the sample supplier, Mrs. Manuela Machado. This paper was supported by the Portuguese Science and Technology Foundation (FCT) under the projects, UID/CVT/00772/2016 and UID/CVT/00772/2019.

\section{References}

American Association of Cereal Chemists - AACC. (1999a). AACC method 30-25.01: Crude fat in wheat, corn, and soy flour, feeds, and mixed feeds (11th ed.). St. Paul: AACC International. http://dx.doi.org/10.1094/AACCIntMethod-30-25.01.

American Association of Cereal Chemists - AACC. (1999b). AACC method 08-01.01: Ash: Basic method (11th ed.). St. Paul: AACC International.

Angelotti, R., Foter, M. J., \& Lewis, K. H. (1961). Time-temperature effects on Salmonellae and Staphylococci in foods: III. Thermal death time studies. Applied Microbiology, 9(4), 308-315. http://dx.doi.org/10.1128/AEM.9.4.308-315.1961

Archer, J., Jervis, E. T., Bird, J., \& Gaze, J. E. (1998). Heat resistance of Salmonella weltevreden in low-moisture environments Journal of Food Protection, 61(8), 969-973. PMid:9713756. http://dx.doi.org/10.4315/0362-028X-61.8.969

Arvanitoyannis, S., \& Bosinas, K. (2006). Bakery products. In S. Arvanitoyannis (Ed.), Modified atmosphere and active packaging technologies (pp. 502-547).Flórida: CRC Press.

Association of Official Analytical Chemists - AOAC. (1990). Official methods of analysis (16th ed.). Washington: AOAC. Australian Standards - AS. (2009a). AS 5013.10-2009: Food microbiology: Microbiology of food and animal feeding stuffs: Horizontal method for the detection of Salmonella spp. (ISO 6579:2002, MOD). Sydney.

Australian Standards - AS. (2009b). AS 5013.24.1-2009: Food microbiology: Microbiology of food and animal feeding stuffs: Horizontal method for the detection and enumeration of Listeria monocytogenes: Detection method (ISO 11290-1:1996, MOD). Sydney.

Bell, C., \& Kyriakides, A. (2002). Salmonella: A pratical approach to the organism and its control in foods. Great Britain: Blackie Academic and Professional.

Blackburn, C. D., Curtis, L. M., Humpheson, L., Billon, C., \& Mcclure, P. J. (1997). Development of thermal inactivation models for Salmonella enteritidis and Escherichia coli $\mathrm{O} 157: \mathrm{H} 7$ with temperature, $\mathrm{pH}$ and $\mathrm{NaCl}$ as controlling factors. International Journal of Food Microbiology, 38(1), 31-44. PMid:9498135. http://dx.doi.org/10.1016/S0168-1605(97)00085-8

Bonner, D., \& Schweiger, M. (1994). Apple pie: An unusual vehicle for food poisoning. Communicable Disease Report. CDR Review, 4(5), R60-R61. PMid:10884860.

British Standards Institution - BSI. (2004). BS ISO 21528-2-2004: Microbiology of food and animal feeding stuffs: Horizontal method for the enumeration of Enterobacteriaceae. Part 2: Colony-count method. London.

Carrasco, E., Morales-Rueda, A., \& García-Gimeno, R. M. (2012). Cross-contamination and recontamination by Salmonella in foods: a review. Food Research International, 45(2), 545-556. http://dx.doi.org/10.1016/j.foodres.2011.11.004

Channaiah, L. H., Michael, M., Acuff, J. C., Phebus, R. K., Thippareddi, H., Olewnik, M., \& Milliken, G. (2017). Validation of the baking process as a kill-step for controlling Salmonella in muffins. International Journal of Food Microbiology, 250, 1-6. http://dx.doi.org/10.1016/j.jifoodmicro.2017.03.007

D’Aoust, J. Y. (1989). Salmonella. In M.P. Doyle (Ed.), Foodborne bacterial pathogens. (pp. 327-445). New York, Marcel Dekker.

D’Aoust, J. Y., \& Maurer, J. (2007). Salmonella species. In M. P. Doyle \& R. L. Buchanan (Eds.), Food microbiology: Fundamentals and frontiers (pp. 187-219). Washington: ASM Press. 
Doyle, M. E., \& Mazzotta, A. S. (2000). Review of studies on the thermal resistance of Salmonellae. Journal of Food Protection, 63(6), 779-795. http://dx.doi.org/10.4315/0362-028X-63.6.779

Evans, M. R., Tromans, J. P., Dexter, E. L. S., Ribeiro, C. D., \& Gardner, D. (1996). Consecutive Salmonella outbreaks traced to the same bakery. Epidemiology and Infection, 116(2), 161-167. PMid:8620907. http://dx.doi.org/10.1017/S0950268800052390

Finn, S., Condell, O., Mcclure, P., Amézquita, A., \& Fanning, S. (2013). Mechanisms of survival, responses, and sources of Salmonella in low-moisture environments. Frontiers in Microbiology, 4, 331. PMid:24294212. http://dx.doi.org/10.3389/fmicb.2013.00331

Food and Agriculture Organization of the United Nations - FAO. (2003). Food energy: Methods of analysis and conversion factors (Technical Workshop, No. 77). Rome: FAO

Garibaldi, J. A., ljichi, K., \& Bayne, H. G. (1969). Effect of pH and chelating agents on the heat resistance and viability of Salmonella Typhimurium tm-1 and Salmonella Senftenberg 775W in egg white. Applied Microbiology, 18(3), 318-322. PMid:4984763. http://dx.doi.org/10.1128/AEM.18.3.318-322.1969

Instituto Português da Qualidade. (1987a). NP 2307:1987: Microbiologia alimentar: Regras gerais para a contagem de microrganismos psicotróficos. Lisboa.

Instituto Português da Qualidade. (1987b). NP 3277-1:1987: Microbiologia alimentar: Contagem de bolores e leveduras. Parte 1: Incubação a $25^{\circ} \mathrm{C}$. Lisboa.

International Commission on Microbiological Specifications for Foods - ICMSF. (1996). Microorganisms in foods 5: Characteristics of microbial pathogens. London: Blackie Academic and Professional.

International Organization for Standardization - ISO. (1999). ISO 6888-2:1999: Microbiology of food and animal feeding stuffs: Horizontal method for the enumeration of coagulase-positive staphylococci (Staphylococcus aureus and other species). Part 2: Technique using rabbit plasma fibrinogen agar medium. Geneva: ISO.

International Organization for Standardization - ISO. (2001). ISO 16649-2:2001: Microbiology of food and animal feeding stuffs: Horizontal method for the enumeration of $\beta$-glucuronidase-positive Escherichia coli. Part 2: Colony-count technique at $44{ }^{\circ} \mathrm{C}$ using 5-bromo-4-chloro-3-indolyl $\beta$-D-glucuronide. Geneva: ISO.

International Organization for Standardization - ISO. (2003). ISO 4833:2003: Microbiology of food and animal feeding stuffs: Horizontal method for the enumeration of microorganisms: Colony-count technique at $30^{\circ} \mathrm{C}$. Geneva: ISO.

International Organization for Standardization - ISO. (2006). ISO 11138-1:2006: Sterilization of health care products: Biological indicators. Part 1: General requirements. Geneva: ISO.

Jay, J. M., Loessner, M. J., \& Golden, D. A. (2005). Modern food microbiology (7th ed.). USA: Springer.

Kapperud, G., Gustavsen, S., Hellesnes, I., Hansen, A. H., Lassen, J., Hirn, J., Jahkola, M., Montenegro, M. A., \& Helmuth, R. (1990). Outbreak of Salmonella typhimurium infection traced to contaminated chocolate and caused by a strain lacking the 60megadalton virulence plasmid. Journal of Clinical Microbiology, 28(12), 2597-2601. PMid:2279988.

http://dx.doi.org/10.1128/JCM.28.12.2597-2601.1990

Lathrop, A. A., Taylor, T., \& Schnepf, J. (2014). Survival of Salmonella during baking of peanut butter cookies. Journal of Food Protection, 77(4), 635-639. PMid:24680076. http://dx.doi.org/10.4315/0362-028X.JFP-13-408

Mackey, B. M., Miles, C. A., Parsons, S. E., \& Seymour, D. A. (1991). Thermal denaturation of whole cells and cell components of Escherichia coli examined by differential scanning calorimetry. Journal of General Microbiology, 137(10), 2361-2374. PMid:1722814. http://dx.doi.org/10.1099/00221287-137-10-2361

Majowicz, S. E., Musto, J., Scallan, E., Angulo, F. J., Kirk, M., O’Brien, S. J., Jones, T. F., Fazil, A., \& Hoekstra, R. M. (2010). The global burden of nontyphoidal Salmonella gastroenteritis. Infectious Diseases Society of America, 50(6), 882-889. PMid:20158401. http://dx.doi.org/10.1086/650733

Mattick, K. L., Jorgensen, F., Legan, J. D., Cole, M. B., Porter, J., Lappin-Scott, H. M., \& Humphrey, T. J. (2000). Survival and filamentation of Salmonella enterica Serovar Enteritidis PT4 and Salmonella enterica Serovar Typhimurium DT104 at low water activity. Applied and Environmental Microbiology, 66(4), 1274-1279. PMid:10742199. http://dx.doi.org/10.1128/AEM.66.4.12741279.2000

Ng, H., Bayne, H. G., \& Garibaldi, J. A. (1969). Heat resistance of Salmonella: the Uniqueness of Salmonella senftenberg 775W. Applied Microbiology, 17(1), 78-82. PMid:5774764. http://dx.doi.org/10.1128/AEM.17.1.78-82.1969

Nguyen, H. T. T., Corry, J. E. L., \& Miles, C. A. (2006). Heat resistance and mechanism of heat inactivation in thermophilic campylobacters. Applied and Environmental Microbiology, 72(1), 908-913. http://dx.doi.org/10.1128/AEM.72.1.908-913.2006

Pajohi-Alamoti, M., Rezaeia, A., \& Mahmoudi, R. (2016). Microbial contamination of pastry cream: Evidence from Hamedan, Iran. Archives of Hygiene Sciences, 5(3), 207-213.

Palumbo, M. S., Beers, S. M., Bhaduri, S., \& Palumbo, S. A. (1995). Thermal resistance of Salmonella spp. and Listeria monocytogenes in liquid egg yolk and egg yolk products. Journal of Food Protection, 58(9), 960-966. PMid:31137409. http://dx.doi.org/10.4315/0362-028X-58.9.960

Peña-Meléndez, M., Perry, J. J., \& Yousef, A. E. (2014). Changes in thermal resistance of three Salmonella serovars in response to osmotic shock and adaptation at water activities reduced by different humectants. Journal of Food Protection, 77(6), 914-918. PMid:24853512. http://dx.doi.org/10.4315/0362-028X.JFP-13-201

Saranraj, P., \& Geetha, M. (2012). Microbial spoilage of bakery products and its control by preservatives. International Journal of Pharmaceutical and Biological Archives, 3(1), 38-48. 
Smith, J. P., Daifas, D. P., El-Khoury, W., Koukoutsis, J., \& El-Khoury, A. (2004). Shelf life and safety concerns of bakery products: A review. Critical Reviews in Food Science and Nutrition, 44(1), 19-55. PMid:15077880. http://dx.doi.org/10.1080/10408690490263774

Tan, K. J., \& Mittal, G. S. (2006). Physicochemical properties changes of donuts during vacuum frying. International Journal of Food Properties, 9(1), 85-98.

Tapia, M. S., Alzamora, S. M., \& Chirife, J. (2007). Effects of water activity (aw) on microbial stability: as a hurdle in food preservation. In G. V. Barbosa-Cánovas, A. J. Fontana Junior, S. J. Schmidt \& T. P. Labuza (Esd.), Water activity in foods: fundamentals and applications (pp. 239-255). Ames: John Wiley \& Sons.

Zhang, G., Ma, L., Patel, N., Swaminathan, B., Wedel, S., \& Doyle, M. P. (2007). Isolation of Salmonella Typhimurium from outbreak associated cake mix. Journal of Food Protection, 70(4), 997-1001. PMid:17477273. http://dx.doi.org/10.4315/0362028X-70.4.997 